\title{
Study of sensory-motor and somatic development of the offspring of rats (Wistar) treated with caffeine
}

\author{
Elthon Gomes Fernandes da Silva*, Alessandro Aires Alexandre, Gerlane Karla Bezerra Oliveira \\ Nascimento, Jaciel Benedito de Oliveira, Elizabeth da Silveira Neves, Austregézilo Vieira da Costa \\ Sobrinho, Maria de Fátima Galdino da Silveira
}

Anatomy Department, Center of Biologic Science, Federal University of Pernambuco

\begin{abstract}
The influence of caffeine, administered to rats, on the somatic and sensory-motor development of the offspring was investigated. Female Wistar rats were divided into a control group and a treated group and received drinking water and a $0.1 \%$ solution of caffeine orally, respectively. The offspring, also divided into a control group and a treated group, received daily monitoring until the $20^{\text {th }}$ day of life to verify alterations in somatic neural development. The offspring of the treated group had reduced weight on the day of birth and on the $1^{\text {st }}, 5^{\text {th }}, 15^{\text {th }}$ and $20^{\text {th }}$ days of life; shorter snout-anus length (evaluation done daily); shorter snout-tail length on the day of birth and on the $1^{\text {st }}, 5^{\text {th }}$ and $10^{\text {th }}$ days of life, and signs of retardation of somatic and sensory-motor maturation. These results allowed the conclusion that administration of caffeine to rats affects somatic and sensory-motor development of offspring.
\end{abstract}

Uniterms: Caffeine/effects. Postnatal development. Central nervous system/stimulants.

Estudou-se a influência da cafeína, administrada a ratos, no desenvolvimento somático e sensorial-motor da prole. Ratos Wistar fêmeas foram divididos em grupo controle e grupo tratado e receberam água e solução de cafeína a $0,1 \%$, respectivamente. A prole, também dividida em grupo controle e grupo tratado, foi monitorada diariamente até o $20^{\circ}$. dia de vida para se observar as alterações no desenvolvimento somático neural. $\mathrm{O}$ grupo tratado apresentou peso reduzido no dia do nascimento e nos $1^{\circ}, 5^{\circ}$., $15^{\circ} \mathrm{e}$ $20^{\circ}$. dias de vida; comprimento focinho-ânus mais curto (avaliação efetuada diariamente); comprimento focinho-cauda mais curto no dia do nascimento e nos $1^{\circ}, 5^{\circ} ., 15^{\circ}$ e $20^{\circ}$. dias de vida e sinais de retardamento da maturação somática e sensorial-motora. Esses resultados permitem que se conclua que a administração da cafeína a ratos afeta o desenvolvimento somático e sensorial-motor da prole.

Unitermos: Cafeína/efeitos. Desenvolvimento pós-natal. Sistema Nervoso Central/estimulantes.

\section{INTRODUCTION}

Physiologic adaptation, also called metabolic programming or metabolic impression, can be activated in an organism when exposed to a particular influence in the intrauterine environment or early stages of life, while still passing through critical phases of tissue and organ development (Barker, 2000).

Any disturbances to the maternal organism before pregnancy can affect the offspring into adult life (Silveira,

\footnotetext{
*Correspondence: E. G. F. da Silva, Universidade Federal de Pernambuco. Centro de Ciências Biológicas. Departamento de Anatomia. Av. Prof. Moraes Rego, 1235 - Cidade Universitária. 51670-420 - Recife - PE, Brasil. E-mail: elthonfernandes@yahoo.com.br
}

2004). If the mother consumes certain substances during pregnancy which cross the placental barrier, the fetus is exposed to these substances and the many effects they can cause.

Caffeine intake in animals is a risk factor due to adverse reproductive effects. Caffeine has a rapid absorption in the gastrointestinal system, and passes into blood and fetal tissues including the central nervous system, when it is administered to the mother (Matijasevich, Santos, Barros, 2005). Highest blood caffeine levels are reached between 3 and 120 minutes, during which time it is rapidly distributed throughout body tissues, achieving equilibrium between blood and tissue levels (Golding, 1995).

Although animal studies indicate that caffeine leads to a decrease in fetal intrauterine growth, low birth weight, 
fetal re-absorption and teratogenesis, these results are still inconclusive in human studies (Souza, Sichieri, 2005). There are reports in the literature of decreased intrauterine growth after mother's consumption of caffeine during pregnancy; however, other articles found no connection between caffeine consumption and low birth weight and prematurity (Bicalho, Barros Filho, 2002), or delayed intrauterine growth (Bicalho, Barros Filho, 2002; Bracken et al., 2003).

In rats, longitudinal growth after birth and after weaning, based on tail length with respect to body length, is used to track body growth (Stewart, Preece, Sheppart, 1975; Barbosa, Santiago, 1994). Other studies have evaluated somatic maturation as a form of corporal growth of these rats (Deiró, 1998; Silveira, 2004; Reis, 2005; Oliveira, 2006).

After birth, the animal's behavior throughout life will be a fundamental part of its adaptation to the environment (Deag, 1981). Responsiveness to environmental factors is related to the level of maturation of the nervous system (Rodriguez-Perez, Vicente-Perez, Garcia, 1992). In this context, this reflex can be characterized: an elementary coordinated motor action that corresponds to a specific sensorial stimulus (Kandel, Schwartz, Jessell, 1992). In recent decades, studies involving growth and development of the nervous system have been featured in the scientific literature. All areas of the nervous system are affected by exogenous factors, for example: dietary alterations and pharmacologic manipulations of neurotransmitters (Deiró, 1998).

Caffeine, commonly used as a psychoactive substance, has been widely studied for its effects on cognitive discharge, although these findings are inconclusive (Lieberman et al., 2002; Perod, Roberts, McKinney, 2000; Sawynok, Yaksh, 1993; Shapkin, 2002). Small doses of caffeine $(60 \mathrm{mg}$ ) alter cognitive function related to alertness, strength, mood, efficiency, and perception of energy (Lieberman, 2001). The substance has also been associated with an increase in motor performance (Fredholm et al. 1999; Johnson-Kozlow et al., 2002; Lieberman et al., 2002; Magill et al., 2003).

Caffeine has been shown to be effective in a onetime dose of $25 \mathrm{mg} / \mathrm{kg}$ to prevent apnea in infants, but it can also result in considerable reduction in the blood flow velocity in cerebral arteries. When the same dose was administered again after 4 hours, velocity of blood flow in the cerebral arteries was decreased after the $2^{\text {nd }}$ dose, while the velocity in intestinal arteries and left ventricle ejection were unaffected (Hoecker et al., 2006).

Caffeine is found in many popular drinks (for example: coffee, tea, soft drinks) (Graham, 1978; Kaminsky,
Fisberg, 1992) which $80 \%$ of the population uses daily; coffee being the most abundant source of caffeine and the most consumed (Camargo, Toledo, 1998). Chocolate and some medicines are other important sources; it has been calculated that approximately 200 non-prescription drugs contain caffeine (Santos et al., 1998).

As it is a non-adaptive drug, when consumed regularly the stimulant effect does not decrease. However, individual sensitivity exists in that small doses can cause tremors, throbbing and anxiety for many hours in some people, while others consuming caffeine daily show no toxic effects for years or decades. Clinical tolerance and habit depend on chronic use of the drug. Individuals drinking 5 or more cups of coffee per day, followed by a period of 12 to 16 hours' abstinence, can present withdrawal symptoms such as headaches, lethargy, irritability and inability to work (Kaminsky, Fisberg, 1992).

Other psychoactive substances causing dependency also present abstinence syndromes: cocaine withdrawal induces somnolence, depression, tiredness, bradycardia; abstinence from marijuana alters sleep and provokes agitation and irritability; nicotine abstinence is associated with appetite increase and weight gain (O'Brien, 2005).

The objective of this study was to investigate the influence of caffeine, administered to rats, on the somatic sensory-motor development during the first 20 days of life.

\section{MATERIAL AND METHODS}

This experiment was approved by the Ethics Committee Responsible for Experiments in Animals at the Center of Biologic Science of the Federal University of Pernambuco (document $n^{\circ} 65 / 06$, process $n^{\circ}$ 013280/2006-31).

In the experiments, twelve rats older than 21 days, weighing between 30-40g were divided into a control group (cg) and treated group ( $\mathrm{tg}$ ) which received a solution of $0.1 \%$ of caffeine, a dose method quoted in the literature by Ohnishi et al. (1986), managed orally by water fountains. The administration of caffeine started on the $21^{\text {st }}$ day of life, when weaning occurs, and continued until weaning of the offspring; the solution of caffeine and the commercial food were offered ad libitum.

After 90 days of life, the rats were mated and during this period the vaginal smear was analyzed with an optical microscope (Carl Zeiss-Germany) to observe the presence of sperm and to detect the beginning of pregnancy. Offspring of the control group (ocg) and the offspring of the treated group (otg), were weighed on a digital scale (Andhr-200, A\&D Company) with sensitivity of $0.001 \mathrm{~g}$ and length of snout-anus (sa) and snout-tail (st) were measured 
with a slide caliper (accuracy $0.05 \mathrm{~mm}$ ) until the $20^{\text {th }}$ day, to test if the somatic neural growth was compromised by treatment.

Indicators adopted for somatic maturation were: ear unfolding (eu), auditory conduit opening (aco), eruption of the lower incisors (ei) and eye opening (eo), as described in the literature (Silveira, 2004; Smart, Dobbing, 1971).

Sensory-motor maturation was evaluated by observation of ontogenic reflexive actions of righting (r), cliff avoidance (ca), auditory startle (as) and free-fall righting (fr) as described elsewhere (Smart, Dobbing, 1971; Rodriguez-Perez, Vicente-Perez, Garcia, 1992; Saste et al., 1998; Silveira, 2004).

Comparisons between treated and control group were performed for each individual period using Student's $t$-Test for independent samples with $* p<0.05$. The results were expressed as mean \pm standard deviation in each treatment group (calculations performed with Microsoft Excel $\left.{ }^{\circledR}\right)$.

\section{RESULTS}

The rats whose mothers were treated with caffeine had lower weight on the day of birth and on the $1^{\text {st }}, 5^{\text {th }}, 15^{\text {th }}$ and $20^{\text {th }}$ days of life with differences of $10.75 \%, 18.95 \%$, $19.49 \%, 15.74 \%, 35.42 \%$, respectively, compared to the control mothers (Figure 1). During the treatment, there was no significant difference in the treated mothers' body weight compared to the control group. The quantity of diluted caffeine consumed versus the consumption of water was an average of $53.28 \mathrm{~mL}$ and $57.85 \mathrm{~mL}$, respectively.

Offspring of rats treated with caffeine (otg) had shorter snout-anus (fa) length of $8.62 \%, 6.39 \%, 13.94 \%$,

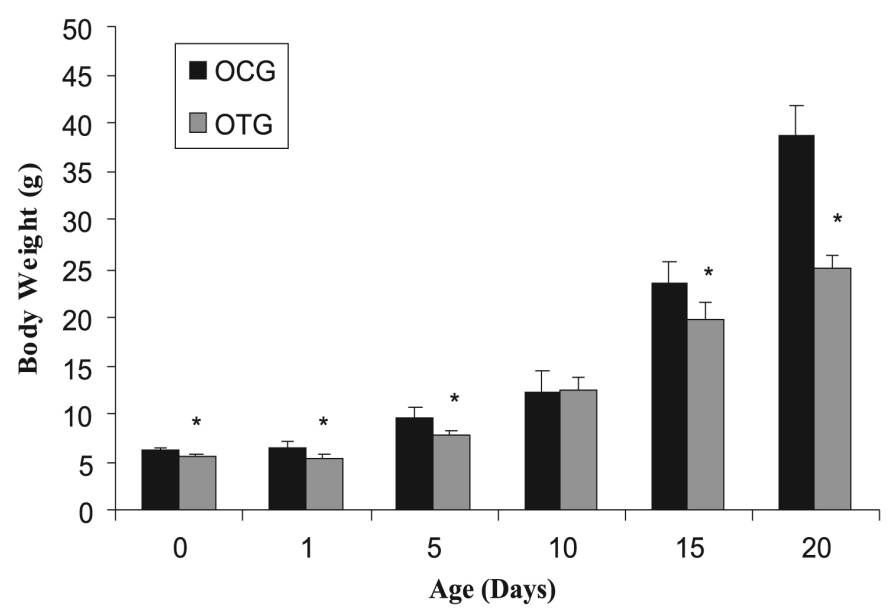

FIGURE 1 - Body weight (grams) as a function of age (days) of the offspring of control rats (ocg) and the offspring of treated rats (otg). Values are expressed as mean \pm standard deviation, $\mathrm{n}=15$ and $* \mathrm{p}<0.05$.
$11.54 \%, 10.37 \%$ and $34.67 \%$ on the day of birth and on the $1^{\text {st }}, 5^{\text {th }}, 15^{\text {th }}$ and $20^{\text {th }}$ days of life, respectively, compared to the offspring of the control group (ocg). Snout-tail (fc) length, in the treated group (otg) showed lower values by $8.43 \%, 7.59 \%, 13.74 \%$ and $12.54 \%$ on the day of birth and on the $1^{\text {st }}, 5^{\text {th }}, 15^{\text {th }}$ and $20^{\text {th }}$ days of life, respectively, compared to the ocg group. (Figures 2 and 3 )

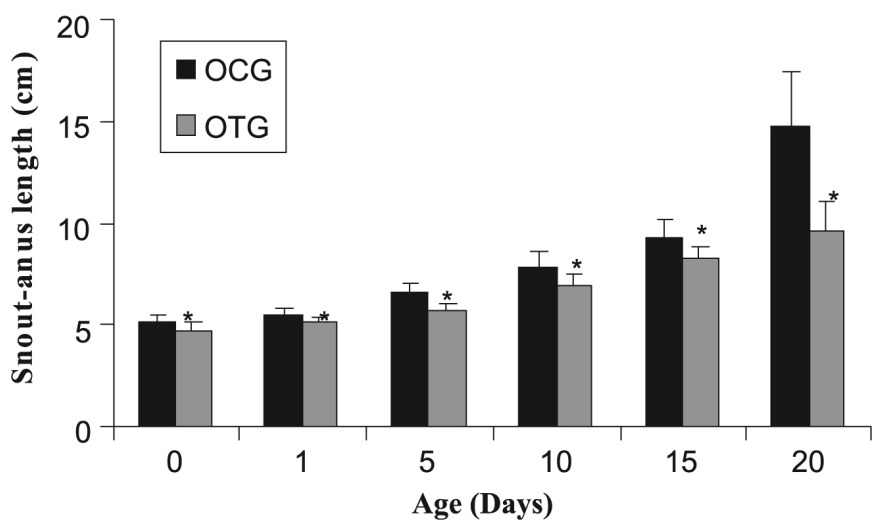

FIGURE 2 - Snout-anus length (centimeters) as a function of age (days) of offspring of control rats (ocg) and of offspring of treated rats (otg). Values were expressed as mean \pm standard deviation, $\mathrm{n}=20$ and $*_{\mathrm{p}}<0.05$.

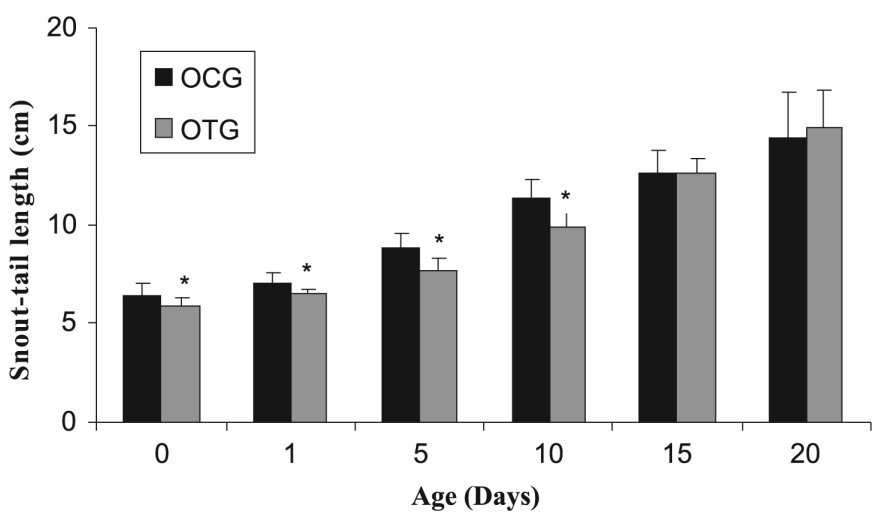

FIGURE 3 - Snout-tail length (centimeters) as a function of age (days) of offspring of control rats (ocg) and offspring of treated rats (otg). The values were expressed as mean \pm standard deviation, $\mathrm{n}=20$ and $* \mathrm{p}<0.05$.

The offspring of rats that consumed caffeine presented retardation in somatic development. The differences in percentage found for the indicators of eu, aco, ei and eo, after comparison of maturation signals between otg and ocg, were $28 \%, 22.3 \%, 11.1 \%$ e $4.1 \%$, respectively (Table I).

The offspring of rats which were administered caffeine presented retardation on the day of appearance of the sensory-motor maturations investigated. According to the day of appearance of the reflexes of $\mathrm{r}$, ca, as and $\mathrm{fr}$, the differences in percentage found, comparing otg 
TABLE I - Somatic development of the offspring of control rats (ocg) and the offspring of rats treated with caffeine (otg). Values expressed as mean \pm standard deviation of age (days), $\mathrm{n}=20 * \mathrm{p}<0.05$

\begin{tabular}{lccc}
\hline $\begin{array}{l}\text { Somatic } \\
\text { development }\end{array}$ & Ocg & Otg & Difference \\
\hline $\mathrm{Eu}$ & $2.50 \pm 0.76$ & $* 3.2 \pm 0.41$ & $-28 \%$ \\
$\mathrm{Aco}$ & $9.85 \pm 0.81$ & $* 12.05 \pm 0.68$ & $-22.3 \%$ \\
$\mathrm{Ei}$ & $12.1 \pm 0.96$ & $* 13.45 \pm 0.51$ & $-11.1 \%$ \\
$\mathrm{Eo}$ & $14.6 \pm 0.99$ & $* 15.2 \pm 0.61$ & $-4.1 \%$ \\
\hline
\end{tabular}

Legend: Eu - ear unfolding; Aco - auditory conduit opening; Ei - eruption of the lower incisors; Eo - eye opening

TABLE II - Sensory-motor development of the offspring of control rats (ocg) and of the offspring of rats treated with caffeine (otg). Values expressed as mean \pm standard deviation of age (days), $\mathrm{n}=20 * \mathrm{p}<0.05$

\begin{tabular}{lccc}
\hline $\begin{array}{l}\text { Sensory-motor } \\
\text { development }\end{array}$ & Ocg & Otg & Difference \\
\hline $\mathrm{R}$ & $1.83 \pm 0.71$ & $* 5.58 \pm 0.79$ & $-204.9 \%$ \\
$\mathrm{Ca}$ & $3.16 \pm 0.85$ & $* 6.11 \pm 0.83$ & $-93.35 \%$ \\
$\mathrm{As}$ & $11.4 \pm 0.88$ & $* 13.25 \pm 0.71$ & $-16.22 \%$ \\
$\mathrm{Fr}$ & $14.3 \pm 0.94$ & $* 16.4 \pm 0.96$ & $-14.68 \%$ \\
\hline
\end{tabular}

Legend: $\mathrm{R}$ - righting; As - auditory startle; $\mathrm{Ca}$ - cliff avoidance; $\mathrm{Fr}-$ free-fall righting

and ocg, were of $204.9 \%, 93.35 \%, 16.22 \%$ and $14.68 \%$, respectively (Table II).

\section{DISCUSSION}

Rats submitted to treatment with caffeine during pregnancy and lactation yielded a higher volume of milk, although the values of the daily total production of proteins, lactose and triglycerides was similar to values observed in females without treatment (Hart, Grimble, 1990).

This could affect the body weight of both offspring groups of this study. However, although caffeine caused weight modifications, only more detailed studies can conclude if the alterations were of metabolic origin (Barker, 2000; Silveira, 2004), or due to congenital metabolic alterations exclusively in the offspring. The findings of weight difference between the groups, corroborate other studies available in the literature (Soyka, 1979; Aeschbacher et al., 1980; Evereklioglu et al., 2003).

During the period of fetal and neonatal development, body tissues are growing (histogenesis) and the so animals grow (Bernardi, 1996). However, appropriate conditions are necessary for a species to reach the correct body gro- wth for age and exposure to some substances can interfere significantly with the growth and maturation process.

Effects of caffeine on body growth of rats are debatable. Caffeine is thought to diminish bone mineral density, which may occur through a change in osteoblast viability, leading to an increase in apoptosis in these cells (Tsuang et al., 2006). Caffeine, associated with a protein diet in rats, is capable of altering the bone mineral content of the mandibula and femur of the offspring. However, treatment with zinc supplements promotes greater than normal bone development in the offspring (Sasahara, Yamano, Nakamoto, 1990).

Effects on growth depend on the concentration of the dose selected for treatment. Daily doses of caffeine, starting on the rats' $5^{\text {th }}$ day of life, were associated with an increase in the blood concentration of growth hormone (GH); however this applies only to the acute effect of the dose. The chronic effect reflected a discreet increase in this concentration, which led some authors to conclude that caffeine was responsible for the depletion of GH in the pituitary gland (Clozel et al., 1983). The way growth hormone $(\mathrm{GH})$ is secreted is an important factor in its metabolic and somatic performance in rodents (Jaffe et al., 2002).

It is possible that the interferences caused by caffeine in the somatic development of the offspring, could be due to toxicological alterations: a substance which can cause retardation in growth or development of specific organs and/or systems can create anatomic and biochemical alterations that generally occur in organisms in the late period of development (Bernardi, 1996).

Another way of accompanying the development of rats is through analysis of reflexive actions. The tests of neurologic analysis support confirmation of retardation or precocity of these actions (Silveira, 2004) and provide information about the capacity of an organism to be responsive to an environmental stimulus without having had previous experience. Neurologic analysis can thus measure effects of environmental factors in maturation of the nervous system and also detect changes in cerebral functions in the presence or absence of answers (Rodriguez-Perez, Vicente-Perez, Garcia, 1992).

Caffeine is one of the substances capable of stimulating the central nervous system (Clozel et al., 1983; Martin et al., 2005). However, it is also a substance that interferes in the formation of the nervous system by acting as an antagonist of adenosine receptors, (the neuromodulator that controls the release of acetylcholine) an important neurotransmitter for cerebral development. It is also described as capable of promoting an increase in the activity of acetyl cholinesterase, an enzyme that inactivates the action of 
acetylcholine (Silva et al., 2008). Another reported injury to the central nervous system due to caffeine is retardation in time of the decubitus reflex in the offspring of rats that consumed caffeine, under the same conditions used in this study (Peruzzi, 1985).

Associating the results on somatic neural development with this information, the values found in the offspring show that, when administered to females, caffeine is responsible for late development in the nervous system of the offspring.

The critical period of cerebral development of the rat, in terms of maturation and sexual differentiation of the brain, occurs between the $6^{\text {th }}$ and $13^{\text {th }}$ day after mating, around the $13^{\text {th }}-14^{\text {th }}$ day of pregnancy until the $21^{\text {st }}$ postnatal day of the offspring (weaning day) (Bernardi, 1996). However according to some studies, manipulations using a psychoactive substance, after the critical period of development, are also capable of altering cerebral development. A chronic dosage of cocaine, when administered subsequent to weaning of the male offspring, exacerbates sexual behavior and diminishes the development of hippocampal cells (Andersen et al., 2007).

According to the data described, an explanation for the fact that the differences between the groups analyzed were more discrepant in the first two cerebral maturation stages was that animals were only mid-way into their development time, where retardation could be the acute cerebral effect of the exposition to the external agent. Smaller differences in the day of appearance of the two last signs of reflex maturation, could be related to the fact that these manifest themselves in a more advanced period of cerebral maturation, suggesting that even when exposed this substance, the cerebral modifications appeared to a lesser degree probably because the nervous system had matured sufficiently to counter act the effects caused by caffeine.

\section{CONCLUSION}

The current study allows us to conclude that the administration of caffeine, during the period between the $21^{\text {st }}$ and $120^{\text {th }}$ days of life, in Wistar rats affects somatic and sensory-motor development of the offspring in the neonatal period, causing: lower weight and corporal size, retardation of somatic maturation signs of auditory external conduct opening, eruption of inferior incisive teeth, auditory pavilion and eye opening, and lateness of sensory-motor maturation signs of decubitus recuperation, of aversion to precipice, of startle and acceleration reactions.

\section{REFERENCES}

AESCHBACHER, H. U.; MILON, H.; POOT, A.; WÜRZNER, H. P. Effect of caffeine on rat offspring from treated dams. Toxicol. Lett., v.7, n.1, p.71-77, 1980.

ANDERSEN, M. L.; PERRY, J. C.; BIGNOTTO, M.; PEREZMENDES, P.; CININI, S. M.; MELLO, L. E.; TUFIK, S. Influence of chronic cocaine treatment and sleep deprivation on sexual behavior and neurogenesis of the male rat. Prog. Neuropsychopharmacol. Biol. Psych., v.31, n.6, p.12241229, 2007.

BARBOSA, L.; SANTIAGO, S. Efecto de la restrición em el consumo de la rata adulta sobre el crescimento y la composición tisular de la cria lactante. Arch. Latinoam. Nutr., v.44, n.2, p.98-104, 1994.

BARKER, D. J. P. In utero programming of cardiovascular disease. Theriogenology., v.53, n.2, p.555-574, 2000.

BERNARDI, M. M. Exposição aos medicamentos durante o período perinatal. In: SPINOSA, H. S.; GÓRNIAK, S. L.; BERNARDI, M. M. (Eds.). Farmacologia aplicada à medicina veterinária. Rio de Janeiro: Guanabara Koogan, 1996. p.517-524.

BICALHO, G. G.; BARROS FILHO, A. A. Peso ao nascer e influência do consumo de cafeína. Rev. Saúde Pública, v.36, n.2, p.180-187, 2002.

BRACKEN, M. B.; TRICHE, E. W.; BELANGER, K; HELLENBRAND, K; LEADERER, B. P. Association of maternal caffeine consumption with decrements in fetal growth. Am. J. Epidemiol., v.157, n.5, p.456-466, 2003.

CAMARGO, M. C. R.; TOLEDO, M. C. F. Teor de cafeína em cafés brasileiros. Ciênc. Tecnol. Aliment., v.18, n.4, p.421424, 1998.

CLOZEL, M.; BRANCHAUD, C. L; TANNENBAUM, G. S.; DUSSAULT, J. H.; ARANDA, J. V. effect of caffeine on thyroid and ptuitary function in newborn Rats. Pediatr. Res., v.17, n.7, p.592-595, 1983.

DEAG, J. M. O comportamento social dos animais. São Paulo: EPU, 1981. 118 p. 
DEIRÓ, T. C. B. J. Desenvolvimento somático e sensório motor e padrão de consumo alimentar em ratos: efeitos do tratamento com inibidor de recaptação de serotonina durante o período de crescimento rápido do encéfalo. Recife, 1998. 117 p. [Dissertação de Mestrado - Centro de Ciências da Saúde. Universidade Federal de Pernambuco].

EVEREKLIOGLU, C.; SARI, I.; ALASEHIRLI, B.; GÜLDÜR, E.; CENGIZ, B.; BALAT, Ö.; BAGCI, C. High dose of caffeine administered to pregnant rats causes histopatological changes in the cornea of newborn pups. Med. Sci. Monit., v.9, n.5, p.208-213, 2003.

FREDHOLM, B. B.; BATTIG, K.; HOLMEN, J.; NEHLIG, A.; ZVARTAU, E. E. Actions of caffeine in the brain with special reference to factors that contribute to its widespread use. Pharmacol. Rev., v.51, p.83-133, 1999.

GOLDING, J. Reproduction and caffeine consumption: a literature review. Early. Hum. Dev., v.43, n.1, p.1-14, 1995.

GRAHAM, D. M. Caffeine-its identity, dietary sources, intake and biological effects. Nutr. Rev., v.36, n.4, p.97-102, 1978.

HART, A.; GRIMBLE, R. F. The effect of methylxanthines on milk volume and composition and growth of rats pups. $\mathrm{Br}$. J. Nut., v.64, n.2, p.339-350, 1990.

HOECKER, C .; NELLE, M .; BEEDGEN, B .; RENGELSHAUSEN, J.; LINDERKAMP, O. Effects of a divided high loading dose of caffeine on circulatory variables in preterm infants. Arch. Dis. Child. Fetal Neonatal Ed., v.91, n.1, p.61-64, 2006.

JAFFE, C. A.; TURGEON, D. K.; LOWN, K.; DEMOTTFRIBERG, R.; WATKINS, P. B. Growth hormone secretion pattern is an independent regulator of growth hormone actions in humans. Am. J. Physiol. Endocrinol. Metab., v.283, n.5, p.1008-1015, 2002.

JOHNSON-KOZLOW, M.; KRITZ-SILVERSTEIN, D.; BARRETT-CONNOR, E.; MORTON, D. Coffee consumption and cognitive function among older adults. Am. J. Epidemiol., v.156, n.9, p.842-850, 2002.

KAMINSKY, S. K.; FISBERG, M. Efeito da cafeína no período gestacional e no concepto. Rev. Femina., v.20, n.2, p.152156, 1992.
KANDEL, E. R.; SCHWARTZ, J. H.; JESSELL, T. M. Fundamentos da neurociência e do comportamento. Rio de Janeiro: Prentice-Hall, 1997. 541 p.

LIEBERMAN, H. R. The effects of ginseng, ephedrine, and caffeine on cognitive performance, mood and energy. Nutr. Rev., v.59, n.4, p.91-102, 2001.

LIEBERMAN, H. R.; THARION, W. J.; SHUKITT-HALE, B.; SPECKMAN, K. L.; TULLEY, R. Effects of caffeine, sleep loss and stress on cognitive performance and mood during U. S. Navy Seal training. Psychopharmacology, v.164, n.3, p.250-261, 2002.

MAGILL, R. A.; WATERS, W. F.; BRAY, G. A.; VOLAUFOVA, J.; SMITH, S. R.; LIEBERMAN, H. R.; MCNEVIN, N.; RYAN, D. H. Effects of tyrosine, phentermine, caffeine $\mathrm{d}$-amphetamine and placebo on cognitive and motor performance deficits during sleep deprivation. Nutr. Neurosc., v.6, n.4, p. 237-246, 2003.

MARTIN, J. V.; NOLAN, B.; WAGNER, G. C.; FISHER, H. Effects of dietary caffeine and alcohol on liver carbohydrate and fat metabolism in rats. Med. Sci. monit., v.10, n.12, p.455-461, 2004.

MATIJASEVICH, A.; SANTOS, I. S.; BARROS, F. C. Does caffeine consumption during pregnancy increase the risk of fetal mortality? Cad. Saúde Pública., v.21, n.6, p.16761684,2005

O'BRIEN, C. P. Drug addiction and drug abuse. In: BRUNTON L. L.; LAZO, J. S.; PARKER, K. L., eds. Goodman and Gilman's the pharmacological basis of therapeutics. 11.ed. New York: Pergamon Press, 2005. p.607-627.

OHNISHI, A.; BRANCH, R. A.; JACKSON, K.; HAMILTON, R.; BIAGGIONI, I.; DERAY, G.; JACKSON, E. K. Chronic caffeine administration exacerbates renovascular, but not genetic, hypertension in rats. J. Clin. Invest., v.78, n.4, p.1045-1050, 1986.

OLIVEIRA, L.S. Manipulações farmacológicas neonatal do sistema noradrenérgico: repercussões sobre o desenvolvimento somático, sensório-motor e sobre o padrão de consumo alimentar adulto. Recife, 2006. 82 p. [Dissertação de Mestrado em Nutrição. Centro de Ciências da Saúde. Universidade Federal de Pernambuco]. 
PEROD, A. L.; ROBERTS, A. E.; McKINNEY, W. M. Caffeine can affect velocity in the middle cerebral artery during hyperventilation, hypoventilation and thinking: a transcranial Doppler study. J. Neuroimaging., v.10, n.1, p.33-38, 2000.

PERUZZI, G.; LOMBARDELLI, G.; ABBRACCHIO, M. P.; COEN, E.; CATTABENI, F. Perinatal caffeine treatment: behavioral and biochemical effects in rats before weaning. Neurobehav. Toxicol. Teratol., v.7, n.5, p.453-460, 1985.

REIS, A. T. P. Ação do hipotireoidismo materno sobre a função auditiva da prole de ratas (wistar). Recife, 2005. $41 \mathrm{p}$. [Monografia de Graduação em Fonoaudiologia. Centro de Ciências da Saúde. Universidade Federal de Pernambuco].

RODRIGUEZ-PEREZ, M. C.; VICENTE-PEREZ, F.; GARCIA, G. G. J. Effects of protein malnutrition and the administration of cortisol on the reflexologic development in rats. Behav. Neural. Biol., v.58, n.3, p.165-170, 1992.

RONDO, P. H.; RODRIGUES, L. C.; TOMKINS, A. M. Coffee consumption and intrauterine growth retardation in Brazil. Eur. J. Clin. Nutr., v.50, n.11, p.705-709, 1996.

SANTOS, I. S.; VICTORA, C. G.; HUTTLY, S.; MORRIS, S. Caffeine intake and pregnancy outcomes: a meta-analytic review. Cad. Saúde Pública., v.14, n.3, p.523-530, 1998.

SASAHARA, H.; YAMANO, H.; NAKAMOTO, T. Effects of maternal caffeine with zinc intake during gestation and lactation on bone development in newborn rats. Arch. Oral. Biol., v.35, n.6, p.425-430, 1990.

SASTE, M. D.; CARVER, J. D.; STOCKARD, J. E.; BENFORD, V. J.; CHEN, L. T.; PHELPS, C. P. Maternal diet fatty acid composition affects neurodevelopment in rat pups. J. Nutr., v.128, n.4, p.740-743, 1998.

SAWYNOK, J.; YAKSH, L. Caffeine as an analgesic adjuvant: a review pharmacology and mechanism of action. Pharmacol. Rev., v.45, n.1, p.43-85, 1993.
SHAPKIN, S. Effect of caffeine on cognitive function and psychophysiological status in man. Fiziol. Cheloveka., v.28, n.1, p.144-150, 2002.

ILVA, R. S.; RICHETTI, S. K.; SILVEIRA, V. G.; BATTASTINI, A. M.; BOGO, M. R.; LARA, D. R.; BONAN, C. D. Maternal caffeine intake affects acetylcholinesterase in hippocampus of neonate rats. Int. J. Dev. Neurosci.,v.26, n.3/4, p.339-343, 2008.

SILVEIRA, M.F.G. Disfunções tireóideas maternas no periodo pré-fecundação programam a função tireóidea e o desenvolvimento somatoneural da prole. Rio de janeiro, 2004. 76 p. [Tese de Doutorado. Instituto de Biologia. Universidade Estadual do Rio de Janeiro].

SMART, J. L.; DOBBING, J. Vulnerability of developing brain. II. Effects of early nutritional deprivation on reflex ontogeny and development of behavior in the rat. Brain Res.,v.28, n.1, p.85-95, 1971.

SOUZA, R. A. G.; SICHIERI, R. Consumo de cafeína e prematuridade. Rev. Nutr., v.18, n.5, p.643-650, 2005.

SOYKA, L. F. Effects of methylxanthines on the fectus. Clin. Perinatol., v.6, n.1, p. 37-51, 1979.

STEWART, R. J. C.; PREECE, R. F.; SHEPPART, H. G. The long-term effects of marginal protein energy deficiency. Proc. Nutr. Soc., v.32, n.3, p.102-103, 1975.

TSUANG, Y. H.; SUN, J. S; CHEN, L. T; SUN, S. C. K; CHEN, S. C. Direct effects of caffeine on osteoblastic cells metabolism: the possible causal effect of caffeine on the formation of osteoporosis. J. Orthop. Surg. v.1, n.7, 2006. Available at: <http://www.josr-online.com/content/ pdf/1749-799x-1-7.pdf>. Acessed on: 29 ago. 2007.

Received for publication on $18^{\text {th }}$ September 2008 . Accepted for publication on $13^{\text {th }}$ July 2009. 
